Огляди літератури, оригінальні дослідження, погляд на проблему, випадок з практики, короткі повідомлення уДК 616.61-036.1-07:[577.17:611.018.2]-085

DOI 10.11603/1811-2471.2020.v.i2.11301

\title{
АДИПОКІНИ ТА ГІПЕРТОНІЧНА ХВОРОБА: КЛІНІЧНЕ ТА ТЕРАПЕВТИЧНЕ ЗНАЧЕННЯ
}

๑Я. М. Філенко

\section{Харківська медична академія післядипломної освіти}

PЕзЮМЕ. В огляді представлені сучасні дані літератури про фізіологічну та патофізіологічну роль гормонів жирової тканини (лептину, резистину, оментину, вісфатину).

Мета - провести аналіз публікацій, що відображають уже відомі аспекти біологічної дії і регуляції адипокінів, та продемонструвати результати останніх досліджень, а також показати тенденції та перспективи розвитку у дослідженні клініко-патогенетичного значення гормонів жирової тканини.

Результати. Основним механізмом негативного впливу жирової тканини на серцево-судинну систему єї̈ гормональна активність. Існує позитивна кореляційна залежність між цифрами артеріального тиску та рівнем адипокінів у плазмі крові. У статті детально розглянута роль адипокінів в розвитку артеріальної гіпертензії, адже вони беруть безпосередню участь у механізмах підвищення артеріального тиску, атерогенезі, регуляції оксидативного стресу, згортанні крові та розвитку неінфекційного запалення В огляді наведені результати зарубіжних досліджень про взаємозв'язок артеріальної гіпертензії, ліпідного обміну та адипокінового дисбалансу.

Висновки. Порушення секреції та функціонування адипокінів можуть бути провідним фактором у розвитку артеріальної гіпертензії та серцево-судинних захворювань. Дані пептиди мають різноспрямований вплив на організм і при порушенні взаємодії сприяють розвитку соціально значущих захворювань, таких як інфаркт міокарда, артеріальна гіпертензія, інсульт, атеросклероз, метаболічний синдром.

КлючОВІ СлОВА: адипокіни; гіпертонічна хвороба; лептин; резистин; оментин; вісфатин.

Адипокіни та гіпертонічна хвороба. Вісцеральна жирова тканина $\epsilon$ ендокринним органом, який секретує широкий спектр біологічно активних речовин - адипокінів, які впливають на процеси прогресування гіпертонічної хвороби, атеросклерозу, тромбоутворення, інсулінорезистентність тощо. Серед них інтерлейкіни, ФНП- $\alpha$, інгібітор тканинного активатора плазміногену-1, ангіотензиноген, лептин, резистин, оментин, вісфатин та інші, більшість з яких мають негативний кардіометаболічний ефект [2].

За даними мета-аналізу великих досліджень, наявність адипокінового дисбалансу асоціюється 3 субклінічним ураженням життєво важливих органів. Це проявляється в зниженні фільтраційної функції нирок, мікроальбумінурії, підвищенні жорсткості артерій, гіпертрофії міокарда лівого шлуночка [3].

Як вже зазначалося раніше, відповідно до рекомендацій ВНОК / РМОАГ [4] Хворі на ГХ з наявністю адипокінового дисбалансу належать до групи високого або дуже високого ризику серцево-судинних ускладнень і терапевтичними цілями у них $\epsilon$, крім контролю АГ, корекція інсулінорезистентності, ендотеліальної дисфункції, дисліпідемії, порушень вуглеводного обміну і вплив на гормони жирової тканини. 3 патогенетичного погляду найбільшою мірою всім цим вимогам відповідають два класи антигіпертензивних лікувальних засобів інгібітори ангіотензинперетворювального ферменту (іАПФ) і бета-адреноблокатори (БАБ) [4].

Особливістю перебігу артеріальної гіпертензії у сучасних умовах $\epsilon$ надзвичайно висока частота коморбідності. Пацієнти з артеріальною гіпер- тензією (АГ) як правило мають одне або декілька супутніх захворювань, найчастішими з яких $\epsilon$ ішемічна хвороба серця (IXC), цукровий діабет, ожиріння, подагра, хронічна хвороба нирок. Сучасні рекомендації Європейського товариства кардіологів та Європейського товариства з артеріальної гіпертензії, Американської асоціації серця та Національна клінічна настанова, які базуються на даних доказової медицини, вказують на необхідність особливих підходів до лікування таких хворих. Клінічний перебіг і прогноз у хворих на АГ значною мірою зумовлені наявністю коморбідних захворювань, що мають негативний вплив на розвиток серцево-судинних ускладнень [3].

Гіпертонічну хворобу (ГХ) має кожен третій дорослий в європейській популяції, і з віком ії частота збільшується. ГХ є провідним кардіоваскулярним фактором ризику, що призводить до інсульту, інфаркту, ниркової та серцевої недостатності. Зростання серцево-судинних захворювань, особливо гіпертонічної хвороби, супроводжується змінами параметрів обміну ліпідів та вуглеводів. Гіпертонічна хвороба та метаболічні зміни характеризуються великою поширеністю і хронічним перебігом, а також збільшенням кількості хворих у популяції. Вісцеральна жирова тканина синтезує і виділяє величезну кількість гормонально-активних речовин, що визначають розвиток харчових розладів, інсулінорезистентності, розвиток цукрового діабету, гіпертонічної хвороби та гіпертрофії лівого шлуночка, дисліпідемії, мікроальбумінурії, гіперкоагуляції [5].

На сьогоднішній день достеменно відомо, що жирова тканина виконує ендокринну функцію та 
Огляди літератури, оригінальні дослідження, погляд на проблему, випадок з практики, короткі повідомлення

підтримує судинний гомеостаз. Усе більше даних свідчать про те, що дисфункція периваскулярної жирової тканини розвивається при певних захворюваннях, таких як ожиріння, порушення обміну речовин. Кровоносні судини оточеніпериваскулярною жировою тканиною, яка складається з кількох типів клітин, серед яких переважають зрілі адипоцити та преадипоцити, та, меншою мірою, мезенхімальні стовбурові клітини. Мезенхімальні стовбурові клітини можуть диференціюватися в адипоцити, остеобласти та ендотеліальні клітини. Інфільтрація макрофагами і Т-клітинами посилюється при запаленні периваскулярної жирової тканини, що й лежить в основі патогенезу судинного запалення [6].

Периваскулярні адипоцити зв'язуються з іншими клітинами периваскулярної жирової тканини та із судинними клітинами, безпосередньо виділяючи адипокіни та секретуючи екзосоми, які містять адипокіни та інші сигнальні молекули. У фізіологічних умовах адипокіни, що секретуються периваскулярними адипоцитами, відіграють важливу роль у регуляції вазомоторного тонусу та судинного гомеостазу, тоді як дисфункціональні периваскулярні адипоцити в умовах запалення продукують цитокіни, такі як ФНП- $\alpha$ (фактор некрозу пухлин $\alpha$ ), IL-6 (інтерлейкін-6) та MCP-1 (monocyte chemoattractant protein-1), що сприяють судинним захворюванням [7].

Периваскулярні адипоцити виділяють фактори, які можуть сприяти звуженню судин, або вазодилатації. У фізіологічних умовах периваскулярні адипоцити в першу чергу чинять судинорозширювальну дію, вивільняючи (ADRF) АДРФ (розслаблюючий фактор адипоцитів), що сприяє розширенню судин через ендотелійзалежний або ендотелійнезалежний механізми, включаючи активацію VSMC (vascular smooth muscle cell) через активацію калієвих каналів [7].

Крім того, адипонектин, що виробляється периваскулярними адипоцитами, може регулювати (AMP-activated protein kinase)-активовану протеїнкіназу для сприятливого моделювання судинного тонусу та ремоделювання. Більше того, оментин, що секретується із здорових периваскулярних адипоцитів, може здійснювати вазопротекцію, інгібуючи активність NOX (NADPH-оксидази) та NF (ядерний фактор). Таким чином, у фізіологічних умовах периваскулярні адипоцити можуть сприяти здоров'ю судин та гомеостазу. Однак в умовах порушення обміну речовин периваскулярні адипоцити стають дисфункціональними, що призводить до зниження вироблення адипонектину та відсутності біодоступності NO й втрати судинорозширювальної функції [8].

Більше того, прозапальні цитокіни, що утворюються під час запалення периваскулярної жиро- вої тканини, посилюють звуження судин та погіршують ендотелійзалежну релаксацію. Ці запальні цитокіни також можуть сприяти проліферації та міграції VSMC (vascular smooth muscle cell). Наприклад, IL-6 збільшує експресію судинних рецепторів AT1 (Ang II [ангіотензин II] рецептора типу 1) і опосередковує медіальну гіпертрофію через комутацію фенотипу VSMC (vascular smooth muscle cell), тоді як МСР-1 чинить паракринну дію на VSMC [9].

Патогенез більшості випадків ГХ у дорослих, як і раніше, залишається недостатньо вивченим. Разом з тим, відкриття біологічних ефектів цитокінів і адипокінів розширило розуміння патофізіологічних механізмів підвищення артеріального тиску (АT). Встановлено, що хронічне запалення і адипокіновий дисбаланс відіграють важливу роль у розвитку ГХ, гіпертензивного ураження органів-мішеней і атеросклерозу, при цьому механізми їх негативного впливу на серцево-судинну систему залишаються предметом наукових досліджень [10].

Тривалий час вчені F. Mallamaci та F. Cuzzola вважали, що адипоцити виконують функцію лише зберігання, мобілізації ліпідів та для метаболічних потреб організму. Однак після тривалих досліджень було встановлено, що адипоцити синтезують понад 50 типів гормонально-активних речовин. Адипокіни беруть участь у ліпідному обміні, сприяють локальному та системному запаленню, але все більшу увагу вони привертають як регулятори артеріального тиску. Адипоцити синтезують i вивільняють фактори, які впливають на рівень артеріального тиску, такі як адипонектин, лептин, вісфатин, апелін, ангіотензин, фактори судинної релаксації та резистин [10].

Існує позитивна кореляційна залежність між цифрами артеріального тиску (АТ) і рівнем лептину плазми, незалежно від наявності ожиріння та артеріальної гіпертензії. Доведено, що тривало існуюча гіперлептинемія збільшує АТ, чинячи вазоконстрикторний ефект через стимуляцію синтезу ендотеліну-1, посилення реабсорбції натрію і оксидативного стресу. Виявлено, що кореляція між АТ і лептином залежить від статі. У здорових жінок вихідні рівні лептину трохи вищі, ніж у популяції здорових чоловіків, але взаємозв'язок між АТ і рівнем лептину більше виражений у чоловіків [10].

Етнічна і расова належність також можуть впливати на взаємозв'язок АТ і лептину. Артеріальна гіпертензія характеризується підвищенням активності симпатичної нервової системи, при цьому b-адренергічна стимуляція призводить до пригнічення експресії гена адипонектину). В свою чергу, гіпоадипонектинемія сприяє активації ренін-ангіотензин-альдостеронової системи в жировій тканині, приводячи до підвищення артеріального тиску [11]. 
Огляди літератури, оригінальні дослідження, погляд на проблему, випадок з практики, короткі повідомлення

В одному з досліджень, яке проводили Р. Piatti, C. Di Mario у тварин, було виявлено, що на тлі дієти з високим вмістом солі і низькими концентраціями адипонектину в плазмі реєструвалися більш високі значення систолічного артеріального тиску, порівняно з групою контролю [12]. Відновлення нормальної секреції адипонектину супроводжувалося нормалізацією цифр АТ. В іншому дослідженні було виявлено, що у пацієнтів з гіпертонічною хворобою і навіть у пацієнтів з дуже високим АТ відзначалася гіпоадипонектинемія [12].

\section{Вплив лікувальної терапії на вміст адипокінів у плазмі крові}

В умовах коморбідності ГХ з адипокіновим дисбалансом, крім основного завдання антигіпертензивної терапії - досягнення цільового артеріального тиску (АТ), дуже важливими стають такі ефекти терапії як органопротекція, здатність зменшувати інсулінорезистентність і прояви метаболічного синдрому, антиатеросклеротична і протизапальна дія. Слід надавати перевагу антигіпертензивним препаратам з високою ліпофільністю, які здатні зменшити продукцію адипокінів та гіперактивацію РААС в периваскулярній та вісцеральній жировій тканині. Згідно з Рекомендаціями з лікування ГХ (ESC, 2013; ESC, 2018), препаратами вибору для стартової терапії є блокатори РАAC, а також блокатори рецепторів ангіотензину (БРА). БРА не тільки не чинять несприятливого впливу на метаболічний профіль хворих, а й збільшують чутливість периферійних тканин до інсуліну, знижують концентрацію атерогенних ліпідів, забезпечують позитивний вплив на вуглеводний і ліпідний обмін. У ряді досліджень доведено зниження рівня прозапальних і протромбогенних адипокінів при призначенні валсартану, телмісартану, олмесартану [13].

Наявність у телмісартану здатності впливати на гамма-PPAR-рецептори забезпечує більш виражений позитивний вплив на запалення та адипокіновий статус у пацієнтів з ГХ. Тому важливо практично оцінити можливі переваги переведення пацієнтів з ГХ із попередньої терапії на препарати групи сартанів з точки зору потенціювання органопротекторних, протизапальних та гіпотензивних ефектів [14].

Крім того, встановлено, що підвищення показників адипонектину плазми можна досягти також застосуванням раміприлу і APA-II (лозартану, валсартану, кандерсатану. AРА-ІІ чинять стимулювальний вплив на рівень адипонектину за допомогою декількох механізмів. Деякі APA-II можуть виступати як активатори ядерних рецепторів PPAR $\gamma$, тим самим індукуючи безпосередньо синтез адипонектину. Так, телмісартан збільшує ак- тивність PPAR $\gamma$ на 30-50 \%. Ірберсартан збільшував рівень адипонектину, знижуючи його внутрішньоклітинну деградацію [14].

Найбільш вивченою групою препаратів, які впливають на секрецію і синтез адипокінів, $є$ блокатори ренін-ангіотензин-альдостеронової системи. Лептин плазми крові корелює з рівнем реніну у пацієнтів з гіпертонічною хворобою. Введення ангіотензину II супроводжується підвищенням утворення вільних кисневих радикалів, які можуть бути одним із чинників, що призводять до зниження продукції адипонектину. В одному з досліджень показано, що антагоністи рецепторів до ангіотензину II зменшують кількість підшкірної і вісцеральної жирової тканини, підвищують чутливість периферійних тканин до інсуліну та зменшують рівень лептину [15].

В іншому дослідженні було виявлено, що терапія раміприлом 10 мг знижувала рівень лептину на $16 \%$, а терапія кандесартаном 16 мг - на $12 \%$ [15].

Блокатори кальцієвих каналів. В одному з досліджень застосування 10 мг амлодипіну було досягнуто зменшення рівня лептину на 12 \%. В іншому дослідженні антагоніст кальцієвих каналів ефонідипін також впливав на значення лептину, зменшуючи його показники на 12 \% від вихідного рівня [16].

Було проведено дослідження, де піндолол показав себе як препарат, що знижує показники лептину плазми. Інший $\beta$-блокатор - атенолол, навпаки, збільшував рівень лептину плазми. Ефекти інших препаратів цього класу не оцінювалися. У пацієнтів з артеріальною гіпертонією, ожирінням і

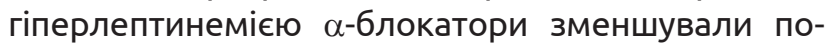
казники лептину плазми при тривалому застосуванні [17].

У роботі Барбараш О., Груздєвой О., Акбашевої О. та інших було показано, що при застосуванні аторвастатину спостерігалося дозозалежне зниження секреції лептину культивованими адипоцитами. Крім того, позитивним ефектом аторвастатину в малій дозі (20 мг/добу) $є$ нормалізація адипокінового статусу, яка проявляється зниженням вмісту лептину та збільшенням протекторного впливу резистину [18].

Висновки. Жирова тканина $є$ активним метаболічним та ендокринним органом, який відіграє ключову роль у розвитку гіпертонічної хвороби, метаболічного синдрому, атеросклерозу та серцево-судинних захворювань. Вивчення впливу адипокінів на патогенез гіпертонічної хвороби і пов'язаних з нею ССЗ може служити предиктором ранньої діагностики, профілактики та лікування вищевказанихзахворювань.Відомо,щозмінаконцентрації різних адипокінів впливає на характер виникнен- 
Огляди літератури, оригінальні дослідження, погляд на проблему, випадок з практики, короткі повідомлення

ня і перебіг прозапальних або протизапальних реакцій. Продукція більшості медіаторів запалення, таких як ФНП, ІЛ-6, при адипокіновому дисбалансі підвищується і сприяє прогресуванню самого захворювання і пов'язаних з ним метаболічних розладів.
Перспективи подальших досліджень. Подальше вивчення клініко-патогенетичного значення гормонів жирової тканини залишається перспективним науковим напрямком для розроблення нових діагностичних та лікувальних алгоритмів з метою оптимізації ведення цих пацієнтів $[7,8]$.

\section{ЛІТЕРАТУРА}

1. Стаценко М. Е. Состояние магистральных артерий, сосудистый возраст у больных артериальной гипертензией и ожирением: роль лептина и адипонектина / М. Е. Стаценко, М.В.Деревянченко // Российский кардиологический журнал. - 2019. - № 24 (1). - С. 7-11. DOI: 10.15829/1560-4071-2019-1-7-11.]

2. Trayhurn P. Signalling role of adipose tissue: adipokines and inflammation in obesity / P. Trayhurn, I. S. Wood // Biochemical Society Transactions. - 2005. - No. 33. P. 1078-1081.

3. Himion L. V. Correction of cardiovascular risk factors in patients with type 2 diabetes mellitus / L. V. Himion, M. O. Rybitskaya // Family Medicine: Scientific-practical Magazine. - 2016. - No. 2. - P. 90-92.

4. Recommendations of the Russian Medical Society for Arterial Hypertension and the All-Russian Scientific Society of Cardiology // Cardiovascular Therapy and Prevention. - 2008. - No. 7 (6).

5. Fitzgibbons T. P. Epicardial and perivascular adipose tis-and clinical associations / T. P. Fitzgibbons, M. P. Czech // J. Am. Heart Assoc. 2014. - No. 3. - P. e000582. DOI: 10.1161/JAHA.113.000582

6. Perivascular adipose tissue in vascular function and disease: a review of current research and animal models / N. K. Brown, Z. Zhou, J. Zhang [et al.] // Arterioscler Thromb Vasc Biol. - 2014. - No. 34. - P. 1621-1630. DOI: 10.1161/ATVBAHA.114.30302.

7. Villacorta L. Chang. The role of perivascular adipose tissue in vaso-constriction, arterial stiffness, and aneurysm / Villacorta L. Chang // Horm. Mol. Biol. Clin. Investig. -2015. No. 21. - P. 137-147. DOI: 10.1515/hmbci-2014-0048

8. Saxton S. N. Emerging roles of sympathetic nerves and inflammation in perivascular adipose tissue /S. N. Saxton, S.B.Withers, A. M. Heagerty//Cardiovasc. Drugs Ther.-2019.No. 33. - P. 245-259. DOI: 10.1007/s10557-019-06862-4

9. Perivascular adipocytes store norepinephrine by vesicular transport / M. F. Ahmad, D. Ferland, N. Ayala-Lopez [et al.] // Arterioscler. Thromb. Vasc. Biol. - 2019. - No. 39. P. 188-199. DOI: 10.1161/ATVBAHA.118.311720
10. Gender-dependent differences in plasma leptin in essential hypertension / F. Mallamaci, F. Cuzzola, G. Tripepi [et al.] // Am. J. Hypertens. - 2000. - No. 13. - P. 914-920.

11. Markers of risk in young offspring with paternal history of myocardial infarction / T. K. Makris, A. N. Hatzizacharias, P. G. Krespi [et al.] // Int. J. Cardiol. -2003. - No. 89. P. 287-293.

12. Association of insulin resistance, hyperleptinemia, and impaired nitric oxide release with in-stent restenosis in patients undergoing coronary stenting / P. Piatti, C. Di Mario, L. D. Monti [et al.] // Circulation. - 2003. - No. 108. P. 2074-2081.

13. Idetification of telmisartan as a unique angiotensin II receptor antagonist with selective / S. C. Benson, H. A. Pershadsingh, C. I. Ho [et al.] // Hypertens. - 2004. No. 43. - P. 993-1002.

14. Effect of valsartan and eprosartan on adiponectin, leptin and insulin sensitivity in hypertensive obese patients / R. Fogari G. Derosa, A. Mugellini [et al.] // J. Hypertens. - 2006. - No. 24. - P. 258-264.

15. Umeda M. Effects of angiotensin II receptor antagonists on insulin resistance syndrome and leptin in sucrosefed spontaneously hypertensive rats / M. Umeda, T. Kanda, M. Murakami // Hypertens Res. -2003. - No. 26. - P. 485-492.

16. Efonidipine simultaneously improves blood pressure, endothelial function, and metabolic parameters in non-diabetic patients with hypertension / K. K. Koh, M. J. Quon, S. J. Lee [et al.] // Diabetes Care. -2007. - No. 30. -P. 1605-1607.

17. An alpha1-receptor blocker reduces plasma leptin levels in hypertensive patients with obesity and hyperleptinemia / S. Ihara, K. Shimamoto, H. Watanabe [et al.] // Hypertens. Res. - 2006. - No. 29. - P. 805-811.

18. Дозозависимые эффекты аторвастатина у пациентов с инфарктом миокарда в госпитальном периоде / О. Л. Барбараш, О. В. Груздева, О. Е. Акбашева [и др.] // Российский кардиологический журнал. - 2013. - № (3). C. 85-92. DOI: 10.15829/1560-4071-2013-3-85-92.

\section{REFERENCES}

1. Statsenko, M.E., \& Derevyanchenko, M.V. (2019). Sostoyaniye magistralnykh arteriy, sosudistyy vozrast u bolnykh arterialnoy gipertenziyey i ozhireniyem: rol leptina $\mathrm{i}$ adiponektina [The state of the main arteries, vascu- lar age in patients with arterial hypertension and obesity: the role of leptin and adiponectin]. Rossiyskiy kardiologicheskiy zhurnal - Russian Journal of Cardiology, 24 (1), 7-11. DOI: 10.15829/1560-4071-2019-1-7-11 [in Ukrainian]. 
Огляди літератури, оригінальні дослідження, погляд на проблему, випадок з практики, короткі повідомлення

2. Trayhurn, P., \& Wood, I.S. (2005). Signalling role of adipose tissue: adipokines and inflammation in obesity. Biochemical Society Transactions, 33, 1078-1081.

3. Himion, L.V., \& Rybitskaya, M.O. (2016). Correction of cardiovascular risk factors in patients with type 2 diabetes mellitus. Family Medicine: Scientific-Practical. Magazine, 2, 90-92.

4. Recommendations of the Russian Medical Society for Arterial Hypertension and the All-Russian Scientific Society of Cardiology. (2008). Cardiovascular Therapy and Prevention, 7 (6).

5. Fitzgibbons, T.P., \& Czech, M.P. (2014). Epicardial and perivascular adipose tis-and clinical associations. J. Am. Heart Assoc., 3, e000582. DOI: 10.1161/JAHA.113.000582.

6. Brown, N.K., Zhou, Z., \& Zhang, J. (2014). Perivascular adipose tissue in vascular function and disease: a review of current research and animal models. Arterioscler Thromb. Vasc. Biol., 34, 1621-1630. DOI: 10.1161/ATVBAHA.114.30302.

7. Chang, V.L. (2015). The role of perivascular adipose tissue in vaso-constriction, arterial stiffness, and aneurysm. Horm. Mol. Biol. Clin. Investig., 21, 137-147. DOI: 10.1515/hmbci-2014-0048.

8. Saxton, S.N., Withers, S.B., \& Heagerty, A.M. (2019). Emerging roles of sympathetic nerves and inflammation in perivascular adipose tissue. Cardiovasc. Drugs Ther., 33, 245-259. DOI: 10.1007/s10557-019-06862-4.

9. Ahmad, M.F., Ferland, D., \& Ayala-Lopez, N. (2019). Perivascular adipocytes store norepinephrine by vesicular transport. Arterioscler Thromb. Vasc. Biol., 39, 188-199. DOI: 10.1161/ATVBAHA.118.311720.

10. Mallamaci, F., Cuzzola, F., \& Tripepi, G. Genderdependent differences in plasma leptin in essential hypertension. Am. J. Hypertens., 13, 914-920.
11. Makris, T.K., Hatzizacharias, A.N., \& Krespi, P.G. (2003). Markers of risk in young offspring with paternal history of myocardial infarction. Int. J. Cardiol., 89, 287-293.

12. Piatti, P., Di Mario, C., \& Monti, L.D. (2003). Association of insulin resistance, hyperleptinemia, and impaired nitric oxide release with in-stent restenosis in patients undergoing coronary stenting. Circulation, 108, 2074-2081.

13. Benson, S.C., Pershadsingh, H.A., \& Ho, C.I. (2004). Identification of telmisartan as a unique angiotensin II receptor antagonist with selective. Hypertens., 43, 9931002.

14. Fogari, R., Derosa, G., \& Mugellini, A. (2006). Effect of valsartan and eprosartan on adiponectin, leptin and insulin sensitivity in hypertensive obese patients. J. Hypertens., 24, 258-264.

15. Umeda, M., Kanda, T., \& Murakami, M. (2003). Effects of angiotensin II receptor antagonists on insulin resistance syndrome and leptin in sucrose-fed spontaneously hypertensive rats. Hypertens. Res., 26, 485-492.

16. Koh, K.K., Quon, M.J., \& Lee, S.J. (2007). Efonidipine simultaneously improves blood pressure, endothelial function, and metabolic parameters in non-diabetic patients with hypertension. Diabetes Care., 30, 1605-1607.

17. Ihara, S., Shimamoto, K., \& Watanabe, H. (2006). An alpha1-receptor blocker reduces plasma leptin levels in hypertensive patients with obesity and hyperleptinemia. Hypertens. Res., 29, 805-811.

18. Barbarash, O.L., Gruzdeva, O.V., \& Akbasheva, O.Ye. Dozozavisimyye effekty atorvastatina u patsiyentov $\mathrm{s}$ infarktom miokarda $v$ gospitalnom periode [Dose-dependent effects of atorvastatin in patients with myocardial infarction in the hospital period]. Rossiyskiy kardiologicheskiy zhurnal - Russian Journal of Cardiology, 3, 85-92. DOI: 10.15829/1560-4071-2013-3-85-92 [in Russian].

\title{
АДИПОКИНЫ И ГИПЕРТОНИЧЕСКАЯ БОЛЕЗНЬ: КЛИНИЧЕСКОЕ И ТЕРАПЕВТИЧЕСКОЕ ЗНАЧЕНИЕ
}

๑Я. Н. Филенко

\author{
Харьковская медицинская академия последипломного образования
}

РЕзЮМЕ. В обзоре представлены современные данные литературы о физиологической и патофизиологической роли гормонов жировой ткани (лептина, резистина, оментина, висфатина).

Цель - провести анализ публикаций, которые отражают уже известные аспекты биологического действия и регуляции адипокинов, и продемонстрировать результаты последних исследований, а также показать тенденции и перспективы развития в исследовании клинико-патогенетического значения гормонов жировой ткани.

Результаты. Основным механизмом негативного влияния жировой ткани на сердечно-сосудистую систему является ее гормональная активность. Существует положительная корреляционная зависимость между цифрами артериального давления и уровнем адипокинов в плазме крови. В статье подробно рассмотрена роль адипокинов в развитии артериальной гипертензии, ведь они принимают непосредственное участие в механизмах повышения артериального давления, атерогенезе, регуляции оксидативного стресса, свертывании крови и развитии неинфекционного воспаления В обзоре приведены результаты зарубежных исследований о взаимосвязи артериальной гипертензии, липидного обмена и адипокинового дисбаланса.

Выводы. Нарушение секреции и функционирования адипокинов может быть ведущим фактором в развитии артериальной гипертензии и сердечно-сосудистых заболеваний. Данные пептиды имеют разнонаправленное влияние на организм и при нарушении взаимодействия способствуют развитию социально значимых заболеваний, таких как инфаркт миокарда, артериальная гипертензия, инсульт, атеросклероз, метаболический синдром.

КЛЮчЕВЫЕ СЛОВА: адипокины; гипертоническая болезнь; лептин; резистин; оментин; висфатин. 
Огляди літератури, оригінальні дослідження, погляд на проблему, випадок з практики, короткі повідомлення

\section{ADIPOKINES AND HYPERTENSION DISEASE: CLINICAL AND THERAPEUTIC VALUE}

๑Y. M. Fylenko

\section{Kharkiv Medical Academy of Postgraduate Education}

SUMMARY. The review presents current data from the literature on the physiological and pathophysiological role of adipose tissue hormones (leptin, resistin, omentin, visfatin).

The aim - to analyze publications that reflect already known aspects of the biological action and regulation of adipokines, and demonstrate the results of recent studies, as well as show trends and development prospects in the study of the clinical and pathogenetic significance of adipose tissue hormones.

Results. The main mechanism of the negative impact of adipose tissue on the cardiovascular system is its hormonal activity. There is a positive correlation between blood pressure figures and plasma adipokines levels. The article discusses in detail the role of adipokines in the development of hypertension, because they are directly involved in the mechanisms of blood pressure, atherogenesis, regulation of oxidative stress, blood clotting and the development of non-infectious inflammation. The review presents the results of foreign studies on the relationship between hypertension, lipid metabolism and adipokine imbalance.

Conclusions. Disorders of adipokines secretion and function may be a leading factor in the development of hypertension and cardiovascular disease. These peptides have different effects on the body and in violation of the interaction contribute to the development of socially significant diseases such as myocardial infarction, hypertension, stroke, atherosclerosis, metabolic syndrome.

KEY WORDS: adipokines; hypertension; leptin; resistin; omentin; visfatin. 